\title{
Eastern Coyotes (Canis latrans var.) consuming large ungulates in a multi-ungulate system
}

\author{
Juliana Balluffi-Fry ${ }^{1,2, *}$, Liane B. Nowell ${ }^{3}$, and Murray M. Humphries ${ }^{1}$ \\ ${ }^{1}$ McGill University, Macdonald Campus, Department of Natural Resource Sciences, 21111 Lakeshore Road, Ste. Anne de \\ Bellevue, Quebec H9X 3V9 Canada \\ ${ }^{2}$ Current address: Memorial University of Newfoundland, Department of Biology, 232 Elizabeth Avenue, St. John's, New- \\ foundland A1B 3X9 Canada \\ ${ }^{3}$ Kenauk Institute, 1000 Chemin Kenauk, Montebello, Quebec J0V 1L0 Canada \\ *Corresponding author: jballuffifry@mun.ca
}

Balluffi-Fry, J., L.B. Nowell, and M.M. Humphries. 2020. Eastern Coyotes (Canis latrans var.) consuming large ungulates in a multi-ungulate system. Canadian Field-Naturalist 134(1): 45-51. https://doi.org/10.22621/cfn.v134i1.2149

\begin{abstract}
The feeding habits of generalist predators often vary among populations and regions. For example, Coyote (Canis latrans), which is a generalist predator distributed across North America, occupies a wide range of habitats and has a highly varied diet. In this observational study, we quantified the presence of mammalian prey items in 50 Eastern Coyote (Canis latrans var.) scats collected in late spring and summer in a private game reserve in southwestern Quebec. Nearly all scats contained hair of White-tailed Deer (Odocoileus virginianus; 44\%), Moose (Alces americanus; 38\%), or American Beaver (Castor canadensis; 38\%). Although all three species are known to be consumed by coyotes, such a high proportion of Moose and White-tailed Deer simultaneously occurring in the diet of coyotes has not been previously reported. The uniqueness of the study area, with its relatively high abundance of all three prey species, may account for the uniqueness of the diet of Eastern Coyotes living there.
\end{abstract}

Key words: Canis latrans; Coyote; Eastern Coyote; Alces americanus; Moose; diet; feeding ecology; foraging ecology; feeding habits; Quebec

\section{Introduction}

Biologists often study animal feeding habits to understand a species' trophic status within its ecological community (Abramsky 1978; Chan et al. 2017). The feeding habits of predators are of particular interest because their regulation of prey populations can maintain ecosystem health (Fortin et al. 2005), but, depending on prey choice, may also affect livestock populations (Hunter and Price 1992; Reynolds and Tapper 1996; Stahler et al. 2006). Coyotes (Canis latrans) have become the apex predator in many North American regions following local eradications of Gray Wolf (Canis lupus) and Cougar (Puma concolor; Goldman 1937; Crooks and Soulé 1999; Laliberte and Ripple 2004; Roemer et al. 2009). This generalist predator is highly flexible and adaptable, causing its ecology to vary greatly by region (Gompper 2002). Because of the coyote's vast geographic range, combined with location-specific ecology, regional observational studies often provide new and important information about coyote behaviour and dietary niche that is relevant to our understanding of coyotes and their role in shaping trophic and community structure.

The forests of rural southern Quebec offer an interesting niche for Eastern Coyotes (Canis latrans var.) to exploit because this area includes the northern range of White-tailed Deer (Odocoileus virginianus), a common prey item, and the southern range of Moose (Alces americanus), which is more often associated with predation by wolves and bears (Ballard and Van Ballenberghe 1998; Snaith and Beazley 2004; Benson and Patterson 2013). Historically, Gray Wolves existed in the area, but they have been extirpated from most of the region (Peterson 1966). At present, Eastern Coyote, which is smaller than wolves but bigger than Western Coyotes (Canis latrans; Way 2007; Way and Hirten 2019), are the only extant canid. Eastern Coyotes are generally thought to have arisen from wolf-coyote hybridization, but the species designation of Eastern Coyote and the extent of gene flow among wolves, coyotes, and Domestic Dogs (Canis familiaris) remains controversial and actively studied (Way and Lynn 2016). 
Studies across eastern North America show coyotes to be dietary generalists, consuming everything from Moose to small rodents, fruits, and plants (Gese and Grothe 1995; Samson and Crete 1997; Crimmins et al. 2012; Dowd and Gese 2012; Swingen et al. 2015). Using scat analysis, we describe the spring and summer vertebrate diet of Eastern Coyotes in a forested area of southwestern Quebec. We predicted that White-tailed Deer would be the most consumed vertebrate, as they are locally abundant and have been previously documented as key items in coyote diet in other parts of Ontario and Quebec with similarly high densities (Poulle et al. 1993; Crete et al. 2001; Sears et al. 2003).

\section{Methods}

\section{Study area}

Our study site was Kenauk Nature, a $265-\mathrm{km}^{2}$ private game reserve (Figure 1), located on the southwest border of Quebec, just north of the Ottawa River between Ottawa and Montréal. The property is crossed by a network of $\sim 100 \mathrm{~km}$ of dirt roads (approximate density $0.4 \mathrm{~km} / \mathrm{km}^{2}$ ). Lying in the transition zone between the St. Lawrence Lowlands and the Laurentian Mountains, the site contains primarily mixed hardwood forest, with many lakes, rivers, and wetlands. The average annual temperature is $4.8^{\circ} \mathrm{C}$ (SD 1.4), the average winter (November-April) temperature is $-4.7^{\circ} \mathrm{C}$ (SD 2.6), and the average summer (MayOctober) temperature is $14.2^{\circ} \mathrm{C}$ (SD 1.2). Average total annual rainfall is $807.4 \mathrm{~mm}$ and total annual snowfall is $178.1 \mathrm{~cm}$ (Environment Canada 2017).

The reserve has a long history of forestry, and active logging still occurs. In 2012, winter aerial surveys of half the property found Moose densities of $\sim 1.0 / \mathrm{km}^{2} ; 2014$ winter surveys of the hunting zone in which the property lies (Zone 10 East) found White-tailed Deer densities of $\sim 2.5 / \mathrm{km}^{2}$ (Ministère des Forêts de la Faune et des Parcs unpubl. data). The density of Eastern Coyotes in the area is unquantified, but they are regularly observed and heard on the property. American Black Bears (Ursus americanus)

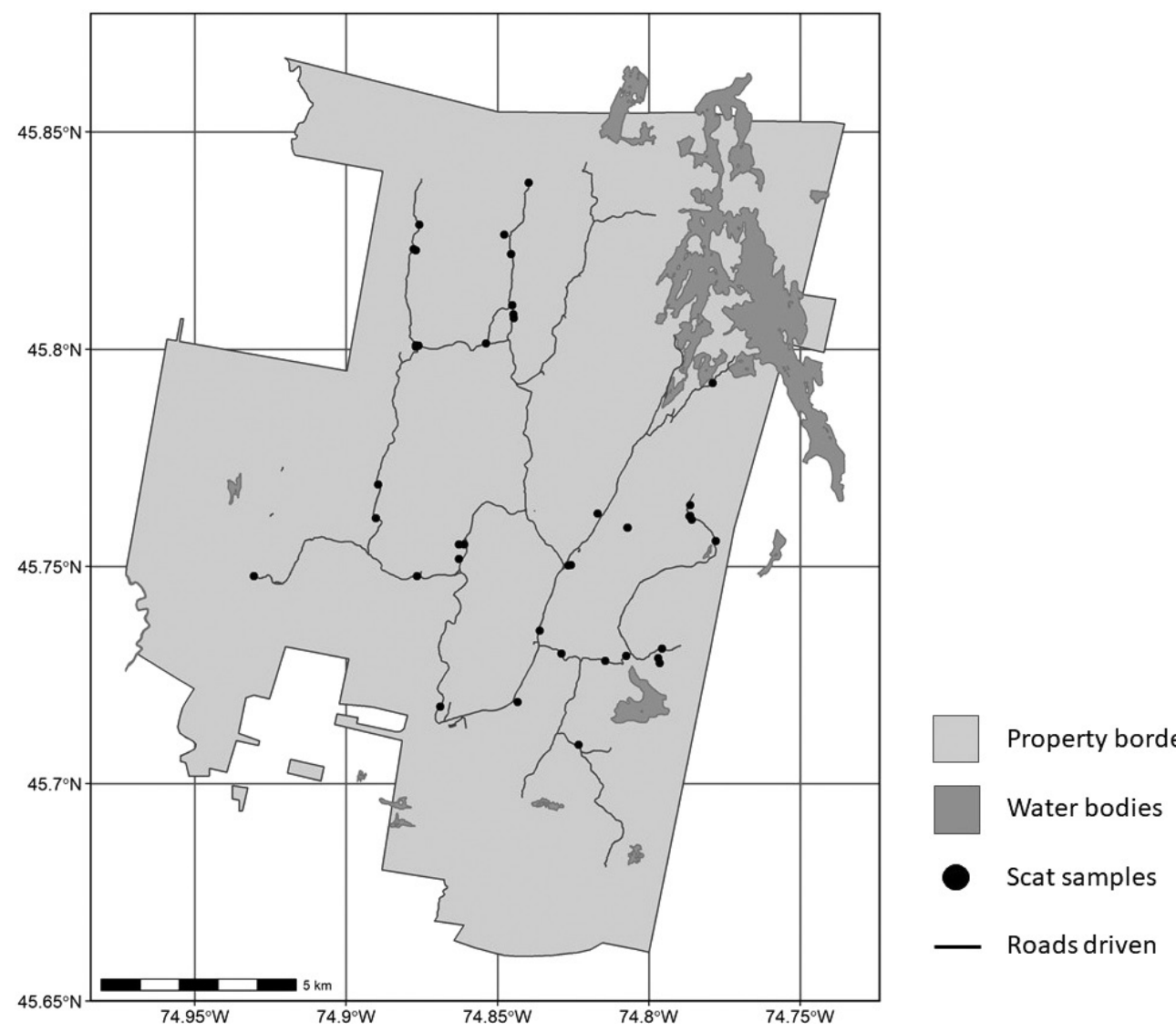

FIGURE 1. Locations of Eastern Coyote (Canis latrans var.) scat collected in 2016 at Kenauk Nature, Quebec, Canada, a $265-\mathrm{km}^{2}$ private game reserve just north of the Ottawa River between Ottawa and Montréal. 
exist on the property, but their densities are also unknown. Canada Lynx (Lynx canadensis) and Bobcat (Lynx rufus) have not been observed, but are potential predators. In autumn, Moose are hunted from about 17 September to 20 October (females and males), and deer are hunted from about 4 to 18 November (males with $\geq 6$ points), each with an annual limit of 10 animals; success rates are higher for Moose (L.B.N. unpubl. data).

\section{Scat collection and predator species confirmation}

Between 23 May and 27 August 2016, we collected coyote scat opportunistically on the property's unpaved road network and occasionally by hiking away from the road network (Figure 1). Coyotes have been found to use tertiary (unpaved) roads all year long, thus supporting our assumption that scat found on the road network would be relatively representative of the property's population (Bensen et al. 2015). We collected scats with a diameter of $\geq 18 \mathrm{~mm}$ to reduce the likelihood of collecting those of foxes or other smaller carnivores (Dumond et al. 2001). We sampled roads daily to once a week during the entire collection period. During roughly the first week of sampling (23-31 May), we cleared the roads of scat, retaining those that appeared fresh (digestive matrix present) and discarding those that consisted of hairs and other hard parts only, with no digestive matrix. Although the age of the first week's collected scats was unknown, we assumed they were from mid to late spring. Subsequently, collected scats were all less than one week old. We placed scats in sealable plastic bags and stored them at $-20^{\circ} \mathrm{C}$ until processing as described in MacCracken and Hansen (1982) and Swingen et al. (2015).

We carried out DNA analysis on a subsample of 28 of the freshest scat (highest moisture content when collected) to confirm they were from coyotes. We thawed the scats and collected $\sim 0.4 \mathrm{~mL}$ of digestive matrix into 1.5-mL microfuge tubes containing 95\% ethanol. Digestive matrix subsamples were stored at $-20^{\circ} \mathrm{C}$ until they were sent to the Canadian Centre for DNA Barcoding in Guelph, Ontario, Canada, for DNA preparation and analysis.

Similar to methods described in Moran et al. (2019), DNA was extracted at the Canadian Centre for DNA Barcoding directly from the homogenate we sent and amplified using vertebrate-specific primers which targetted a 185-base-pair fragment of the cytochrome c oxidase I (COI) barcode region of mtDNA. DNA was sequenced with an Ion Torrent PGM high-throughput sequencer (Thermo Fisher, Waltham, Massachusetts, USA ). The raw sequence reads were demultiplexed into 30 datasets that included the 28 faecal samples and two negative controls, filtered to remove low-quality reads, and trimmed to remove primer sequences. The reads were then clustered into operational taxonomic units (OTUs) based on $98 \%$ identity and a minimum of 10 reads per OTU. Although the COI barcode region for wolves and coyotes is $95.8 \%$ identical, six diagnostic nucleotides can be used to distinguish them and confirm maternal heritage. These methods also amplified some prey DNA, but we did not use such DNA for our dietary analysis.

\section{Dietary analysis}

Scats were individually thawed, dried, and cleaned until only hard parts remained. We selected up to 10 guard hairs from across each cleaned scat for identification (Forbes and Theberge 1996 found that three hairs per scat accounted for $98.8 \%$ of prey items in wolf scat). We assessed each hair's macro-qualities (colour, length, width, texture, and shape), medulla patterns, and scale patterns of the guard hairs and compared these against known hair samples and guides (Moore et al. 1974). We identified Cervidae to species level (i.e., White-tailed Deer or Moose) and other prey to the family level. We distinguished among larger Rodentia species, American Beaver (Castor canadensis) and North American Porcupine (Erethizon dorsatum), but grouped small rodents into one prey group. We also recorded the presence of avian feathers found in the scats.

\section{Results}

We collected 50 scats from 23 May to 27 August, the first five of which we assumed to have been deposited in spring (April), but we do not know the precise date. Only one sample was found off roads. Although scats were never found in some sections of road, scats were distributed fairly evenly across the monitored area (Figure 1). All 28 samples sent for DNA analysis confirmed coyote maternal origin. On six occasions, we collected multiple scats at a single location and time, but in only one of these cases did scats collected together have identical dietary findings (samples 48 and 49; Table S1). The three most commonly found diet items, based on simple occurrence rate, were White-tailed Deer (0.44), Moose (0.38), and beaver (0.38; Table 1$)$. We also observed mustelids $(0.10)$, non-beaver rodents $(0.04)$, and bird and feline species, which we categorized as "other" (0.04; Table $1)$. We did not find any lagomorph or porcupine remains in any of the scats. Although we did not distinguish between juvenile and adult ungulates, Moose hair was often thin and weak in structure, which, we speculate, could indicate that most consumed Moose were calves (Adorjan and Kolenosky 1969).

Most scats $(n=32)$ contained only a single type of hair, while the remainder had either two $(n=16)$ or three hair types $(n=2$; Table S1). Samples never con- 
Table 1. Diet items detected in 50 Eastern Coyote (Canis latrans var.) scat samples collected in 2016 at Kenauk Nature, Quebec, Canada.

\begin{tabular}{|c|c|c|c|}
\hline \multicolumn{2}{|l|}{ Species/taxa } & \multicolumn{2}{|c|}{$\begin{array}{c}\text { Samples in } \\
\text { which diet item } \\
\text { found }(n=50)\end{array}$} \\
\hline Common name & Scientific name & No. & $\%$ \\
\hline White-tailed Deer & Odocoileus virginianus & 22 & 44 \\
\hline Moose & Alces americanus & 19 & 38 \\
\hline American Beaver & Castor canadensis & 19 & 38 \\
\hline Mustelid & Mustelidae & 5 & 10 \\
\hline Non-beaver rodent & t Rodentia & 2 & 4 \\
\hline Other & - & 2 & 4 \\
\hline
\end{tabular}

tained both Moose and White-tailed Deer, and beaver hair was found both alone and paired with ungulate hair (Figure 2). Of scats containing two hair types, most consisted of beaver and an ungulate.

\section{Discussion}

White-tailed Deer, beaver, and Moose were all detected in coyote scats at similar rates, and each was detected throughout the study period from May to August (Table S1). In addition, although individual scats often contained both beaver and Moose or beaver and deer, we did not find any scats that contained both species of ungulates. A Moose or deer could feed multiple coyotes or a few coyotes over multiple days, whereas beavers are smaller and likely cannot; thus, a specific Moose or deer may be represented in

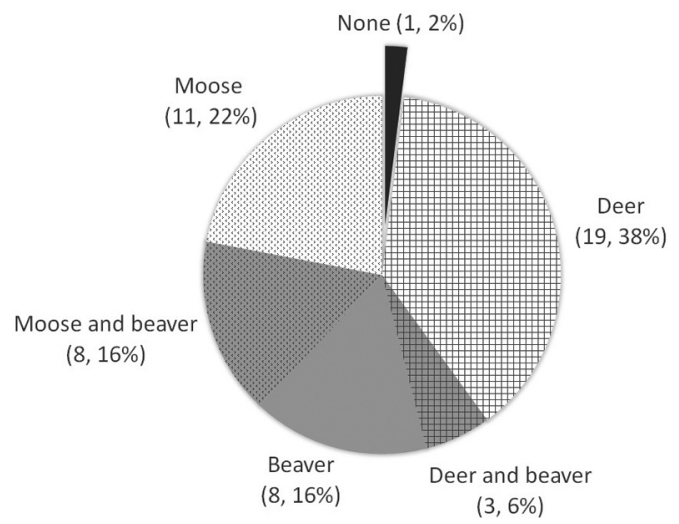

Figure 2. Detection rates for each hair type (number, \%) in 50 analyzed Eastern Coyote (Canis latrans var.) scats, including the three most common items: Moose (Alces americanus), White-tailed Deer (Odocoileus virginianus), and American Beaver (Castor canadensis), and their combined detections. One detection equals one scat and, hence, reflects prey importance; no sample is represented by multiple categories. The category "None" represents the only sample that did not contain Moose, White-tailed Deer, or beaver, but remains of small rodents only. multiple samples. Our results, therefore, suggest that deer, Moose, and beaver are the primary diet items of Eastern Coyotes in this reserve during the spring and summer. A study from a neighbouring area in southeastern Ontario also found deer and beaver to be common summer diet items (Sears et al. 2003). Although our results were in line with our prediction that Whitetailed Deer would be the most common diet item, we did not expect such a high occurrence of Moose.

Many other studies from Quebec and surrounding areas have found Moose to be absent or rare in coyote diets (Richens and Hugie 1974; Messier et al. 1986; Poulle et al. 1993; Patterson et al. 1998; Crete et al. 2001; Sears et al. 2003). Although there are also reports of high Moose consumption and low deer consumption in Quebec and New Brunswick (Samson and Crete 1997; Dumond et al. 2001; Boisjoly et al. 2010; Power et al. 2019), these studies have been carried out in areas with reported high Moose densities compared with deer. A dramatic change in coyote summer diet, from White-tailed Deer as the primary ungulate consumed in 1988 to Moose by 1991, was observed in Gaspésie, Quebec (Samson and Crete 1997). During that time, deer numbers decreased greatly (based on a $76.9 \%$ decline in harvest rate), while Moose densities increased (based on a $15.1 \%$ increase in harvest rate), which the authors hypothesized as the reason for the change in diet. None of these studies show a similar occurrence rate for both Moose and deer in the diet over the same period of time, which makes our observation, even with a small sample size, notable.

Our unique observation of similarly high rates of Moose and deer consumption by Eastern Coyotes could be explained by the relatively high densities of both ungulates in our study area. Moose and Whitetailed Deer ranges overlap at their southern and northern extents. The eastern area of their sympatric range grew to its current size only after land clearing in the 20th century, when deer extended their range north, causing Moose densities to decline, likely in part because of the spread of meningeal worm, Parelaphostrongylus tenuis (Boer 1998). Given that White-tailed Deer carry, but are not affected by this parasite, which kills Moose, it is often assumed and frequently reported that densities of these two ungulates are inversely related in eastern regions (Whitlaw and Lankester 1994). Hence, few if any coyote feeding studies have been conducted where Moose and deer are present at high abundances. We do not know the reason for our study area's high densities of both Moose and deer, but one explanation could be that the historical strip cuts and current logging practices have created ample forage. We have yet to learn the current status of $P$. tenuis in our study area. 
We speculate that most of the Moose consumed were calves, based on other literature and characteristics of both Moose and White-tailed Deer, although we cannot distinguish between predation and scavenging. The vast majority of the scats collected (Table S1) were deposited during or after the window of Moose parturition in this region (Musante et al. 2010). Juvenile Moose are also smaller and less coordinated than adult White-tailed Deer, which Eastern Coyotes are known to predate (Poulle et al. 1993; Chitwood et al. 2014). It is commonly believed that coyotes are incapable of predating healthy, adult Moose, except during the winter months when snow can severely limit ungulate movement (Benson and Patterson 2013). We speculate that the Moose found in the first week's samples were scavenged or predated adult/yearling Moose from the spring (before the window of parturition) when the body condition of Moose is poor (Musante et al. 2010).

Having a better understanding of Eastern Coyote dietary patterns in the region, in particular what age classes and conditions of ungulates they consume, would help wildlife managers to quantify the influence of Eastern Coyotes on the local ungulate populations. Future work on coyote feeding habits in this reserve should include collecting more scats across multiple seasons and an age-class analysis of hairs in scats. It is possible that coyotes consume newborn Moose calves in the summer (a pulsed resource) and adults in the winter when they are made more vulnerable by snow and poor body condition (Benson and Patterson 2013). Kill site investigations, best located with global positioning system units on predators (Franke et al. 2006), would also help identify the species, age, and condition of larger prey and better determine whether hairs in the diet were from predation or scavenging events. In addition, sampling for $P$. tenuis should occur to learn whether a lack of $P$. tenuis promotes the high densities of Moose and Whitetailed Deer or if they co-occur despite the parasite.

\section{Author Contributions}

Writing - Original draft: J.B.; Writing - Review \& Editing: J.B., L.B.N., and M.M.H.; Conceptualization: J.B., L.B.N., and M.M.H.; Investigation: J.B.; Methodology: J.B.; Formal Analysis: J.B.; Funding Acquisition: L.B.N.; Resources: M.M.H.; Project Administration: L.B.N.; Supervision: M.M.H. and L.B.N.; Visualization: J.B.

\section{Acknowledgements}

This study was part of research for an honours thesis at McGill University's department of Natural Resource Sciences and was housed and supported by the Kenauk Institute. Andre Dumont from the Mini- stère des Forêts de la Faune et des Parcs supplied us with unpublished Moose and deer density counts for our study site description. The Canadian Centre for DNA Barcoding performed our predator DNA analysis for which we thank Sean Prosser for primary communications. We would like to thank E. Hance Ellington for critical evaluation and valuable editing of the manuscript, Christina Prokopenko for reviewing and giving commentary, Manuelle LandryCuerrier for assisting with project logistics, and Jessica Turgeon, Katrina Di Bacco, Celine Pichett, and Bill Nowell for scat collection help. Finally, thanks to Emina Ida, Josephine Purdy, and Daphné Bourget for assisting with the sorting of scat remains.

\section{Literature Cited}

Abramsky, Z. 1978. Small mammal community ecology. Oecologia 34: 113-123. https://doi.org/10.1007/bf0 0345160

Adorjan, A.S., and G.B. Kolenosky. 1969. A Manual for the Identification of Hairs of Selected Ontario Mammals. Ontario Department of Lands and Forests, Toronto, Ontario, Canada.

Ballard, W.B., and V. Van Ballenberghe. 1998. Predator/ prey relationships. Pages 247-273 in Ecology and Management of the North American Moose. Edited by A.W. Franzmann and C.C. Schwartz. Wildlife Management Institute, Washington, DC, USA.

Benson, J.F., P.J. Mahoney, and B.R. Patterson. 2015. Spatiotemporal variation in selection of roads influences mortality risk for canids in an unprotected landscape. Oikos 124: 1664-1673. https://doi.org/10.1111/oik.01883

Benson, J.F., and B.R. Patterson. 2013. Moose (Alces alces) predation by eastern coyotes (Canis latrans) and eastern coyote $\times$ eastern wolf (Canis latrans $\times$ Canis lycaon) hybrids. Canadian Journal of Zoology 91: 837841. https://doi.org/10.1139/cjz-2013-0160

Boer, A.H. 1998. Interspecific relationships. Pages 337350 in Ecology and Management of the North American Moose. Edited by A.W. Franzmann and C.C. Schwartz. Wildlife Management Institute, Washington, DC, USA.

Boisjoly, D., J.P. Ouellet, and R. Courtois. 2010. Coyote habitat selection and management implications for the Gaspésie Caribou. Journal of Wildlife Management 74: 3-11. https://doi.org/10.2193/2008-149

Chan, K., S. Boutin, T.J. Hossie, C.J. Krebs, M. O'Donoghue, and D.L. Murray. 2017. Improving the assessment of predator functional responses by considering alternate prey and predator interactions. Ecology 98: 1787-1796. https://doi.org/10.1002/ecy.1828

Chitwood, M.C., M.A. Lashley, C.E. Moorman, and C.S. DePerno. 2014. Confirmation of coyote predation on adult female white-tailed deer in the southeastern United States. Southeastern Naturalist 13: N30-N32. https://doi.org/10.1656/058.013.0316

Crête, M., J.P. Ouellet, J.P. Tremblay, and R. Arsenault. 2001. Suitability of the forest landscape for coyotes in northeastern North America and its implications for co- 
existence with other carnivores. Écoscience 8: 311-319. https://doi.org/10.1080/11956860.2001.11682658

Crimmins, S.M., J.W. Edwards, and J.M. Houben. 2012. Canis latrans (Coyote) habitat use and feeding habits in central West Virginia. Northeastern Naturalist 19: 411420. https://doi.org/10.1656/045.019.0304

Crooks, K.R., and M.E. Soulé. 1999. Mesopredator release and avifaunal extinctions in a fragmented system. Nature 400: 563-566. https://doi.org/10.1038/23028

Dowd, J.L.B., and E.M. Gese. 2012. Seasonal variation of coyote diet in northwestern Wyoming: implications for dietary overlap with Canada lynx? Northwest Science 86: 289-299. https://doi.org/10.3955/046.086.0405

Dumond, M., M.A. Villard, and E. Tremblay. 2001. Does coyote diet vary seasonally between a protected and unprotected forest landscape? Écoscience 8: 301-310. https://doi.org/10.1080/11956860.2001.11682657

Environment Canada. 2017. National climate data and information archive. Environment Canada, Ottawa, Ontario, Canada. Accessed December 2017. https://climate. weather.gc.ca/climate_normals/results_1981_2010_ e.html?stnID=5612\&autofwd $=1$.

Forbes, G.J., and J.B. Theberge. 1996. Response by wolves to prey variation in central Ontario. Canadian Journal of Zoology 74: 1511-1520. https://doi.org/10.1139/z96-165

Fortin, D., H.L. Beyer, M.S. Boyce, D.W. Smith, T. Duchesne, and J.S. Mao. 2005. Wolves influence elk movements: behavior shapes a trophic cascade in Yellowstone National Park. Ecology 86: 1320-1330. https:// doi.org/10.1890/04-0953

Franke, A., T. Caelli, G. Kuzyk, and R.J. Hudson. 2006. Prediction of wolf (Canis lupus) kill-sites using hidden Markov models. Ecological Modelling 197: 237-246. https://doi.org/10.1016/j.ecolmodel.2006.02.043

Gese, E.M., and S. Grothe. 1995. Analysis of coyote predation on deer and elk during winter in Yellowstone National Park, Wyoming. American Midland Naturalist 133: 36-43. https://doi.org/10.2307/2426345

Goldman, E.A. 1937. The wolves of North America. Journal of Mammalogy 18: 37-45. https://doi.org/10.2307/13 74306

Gompper, M.E. 2002. Top carnivores in the suburbs? Ecological and conservation issues raised by colonization of northeastern North America by coyotes. Bioscience 52: 185-190. https://doi.org/10.1641/0006-35 68(2002)052[0185:tcitse]2.0.co;2

Hunter, M.D., and P.W. Price. 1992. Playing chutes and ladders: heterogeneity and the relative roles of bottomup and top-down forces in natural communities. Ecology 73: 724-732. https://doi.org/10.2307/1940152

Laliberte, A.S., and W.J. Ripple. 2004. Range contractions of North American carnivores and ungulates. AIBS Bulletin 54: 123-138. https://doi.org/10.1641/00 06-3568(2004)054[0123:rconac]2.0.co;2

MacCracken, J.G., and R.M. Hansen. 1982. Seasonal foods of coyotes in southeastern Idaho: a multivariate analysis. Great Basin Naturalist 42: 45-49.

Messier, F., C. Barrette, and J. Huot. 1986. Coyote predation on a white-tailed deer population in southern Quebec. Canadian Journal of Zoology 64: 1134-1136. https://doi.org/10.1139/z86-170
Moore, T.D., L.E. Spence, and C.E. Dugnolle. 1974. Identification of the dorsal guard hairs of some mammals of Wyoming. Bulletin 14. Wyoming Game and Fish Department, Cheyenne, Wyoming, USA.

Moran, A.J., S.W. Prosser, and J.A. Moran. 2019. DNA metabarcoding allows non-invasive identification of arthropod prey provisioned to nestling Rufous hummingbirds (Selasphorus rufus). PeerJ 7: e6596. https:// doi.org/10.7717/peerj.6596

Musante, A.R., P.J. Pekins, and D.L. Scarpitti. 2010. Characteristics and dynamics of a regional moose Alces alces population in the northeastern United States. Wildlife Biology 16: 185-204. https://doi.org/10.2981/09-014

Patterson, B.R., L.K. Benjamin, and F. Messier. 1998. Prey switching and feeding habits of eastern coyotes in relation to snowshoe hare and white-tailed deer densities. Canadian Journal of Zoology 76: 1885-1897. https:// doi.org/10.1139/z98-135

Peterson, R.L. 1966. The Mammals of Eastern Canada. Oxford University Press, Toronto, Ontario, Canada.

Poulle, M., M. Crête, J. Huot, et R. Lemieux. 1993. Prédation exercée par le Coyote, Canis latrans, sur le Cerf de Virginie, Odocoileus virginianus, dans un ravage en déclin de 1'Est du Québec. Canadian Field-Naturalist 107: 177-185. Accessed 24 April 2020. https://www.bio diversitylibrary.org/page/34810311.

Power, J.W.B., M.J. Boudreau, E.M. Muntz, and S. Bondrup-Nielsen. 2019. High reliance on a diet of Moose (Alces americanus) by Eastern Coyotes (Canis latrans var.) in Cape Breton Highlands National Park, Nova Scotia, Canada. Canadian Field-Naturalist 133: 329-331. https://doi.org/10.22621/cfn.v133i4.2138

Reynolds, J.C., and S.C. Tapper. 1996. Control of mammalian predators in game management and conservation. Mammal Review 26: 127-155. https://doi.org/10.11 11/j.1365-2907.1996.tb00150.x

Richens, V.B., and R.D. Hugie. 1974. Distribution, taxonomic status, and characteristics of coyotes in Maine. Journal of Wildlife Management 38: 447-454. https:// doi.org/10.2307/3800875

Roemer, G.W., M.E. Gompper, and B. Van Valkenburgh. 2009. The ecological role of the mammalian mesocarnivore. BioScience 59: 165-173. https://doi.org/10.1525/ bio.2009.59.2.9

Samson, C., and M. Crête. 1997. Summer food habits and population density of coyotes, Canis latrans, in boreal forests of southeastern Quebec. Canadian FieldNaturalist 111: 227-233. Accessed 24 April 2020. https:// www.biodiversitylibrary.org/page/35481769.

Sears, H.J., J.B. Theberge, M.T. Theberge, I. Thornton, and G.D. Campbell. 2003. Landscape influence on Canis morphological and ecological variation in a coyote-wolf C. lupus $\times$ latrans hybrid zone, Southeastern Ontario. Canadian Field-Naturalist 117: 591-600. https:// doi.org/10.22621/cfn.v117i4.828

Snaith, T.V., and K.F. Beazley. 2004. The distribution, status and habitat associations of moose in mainland Nova Scotia. Proceedings of the Nova Scotian Institute of Science 42: 263-317.

Stahler, D.R., D.W. Smith, and D.S. Guernsey. 2006. 
Foraging and feeding ecology of the gray wolf (Canis lupus): lessons from Yellowstone National Park, Wyoming, USA. Journal of Nutrition 136: 1923S-1926S. https://doi.org/10.1093/jn/136.7.1923S

Swingen, M.B., C.S. DePerno, and C.E. Moorman. 2015. Seasonal coyote diet composition at a low-productivity site. Southeastern Naturalist 14: 397-404. https://doi.org/ 10.1656/058.014.0219

Way, J.G. 2007. A comparison of body mass of Canis latrans (coyotes) between eastern and western North America. Northeastern Naturalist 14: 111-124. https://oi.org/10. 1656/1092-6194(2007)14[111:acobmo]2.0.co;2

Way, J.G., and J.L. Hirten. 2019. Wild Canis spp. of North
America: a pictorial representation. Canadian FieldNaturalist 133: 295-296. https://doi.org/10.22621/cfn.v $133 \mathrm{i} 3.2473$

Way, J.G., and W.S. Lynn. 2016. Northeastern coyote/coywolf taxonomy and admixture: a meta-analysis. Canid Biology \& Conservation 19: 1-7.

Whitlaw, H.A., and M.W. Lankester. 1994. The co-occurrence of moose, white-tailed deer, and Parelaphostrongylus tenuis in Ontario. Canadian Journal of Zoology 72: 819-825. https://doi.org/10.1139/z94-111

Received 29 October 2018

Accepted 10 April 2020

\section{Supplementary Material:}

Table S1. Location and prey content of 50 Eastern Coyote (Canis latrans var.) scat samples collected in 2016 at Kenauk Nature, Quebec, Canada. 